NBER WORKING PAPER SERIES

\title{
BLACK/WHITE DIFFERENCES IN WEALTH AND ASSET COMPOSITION
}

Francine D. Blau

John W. Graham

Working Paper No. 2898

\author{
NATIONAL BUREAU OF ECONOMIC RESEARCH \\ 1050 Massachusetts Avenue \\ Cambridge, MA 02138 \\ March 1989
}

\begin{abstract}
We are grateful for the helpful comments of Lawrence Kahn, Joseph Altonji, Earl Grinols, and Daniel Hamermesh, and for the research assistance of Susan Schwochau, Bruce Lawrence, Keith Chauvin, Ed Sexton, Laura Mayer, and Denise Dorigo. Research support by the Research Board of the University of Illinois and by the Rutgers Research Council is gratefully acknowledged. This paper is part of NBER's research program in Labor Studies. Any opinions expressed are those of the authors not those of the National Bureau of Economic Research.
\end{abstract}




\section{March 1989 \\ BLACK/WHITE DIFFERENCES IN WEALTH AND
ASSET CONSUMPTION}

NBER Working Paper \#2898

\section{ABSTRACT}

Using data from the 1976 and 1978 National Longitudinal Surveys of young men and young women, this study examines racial differences in the magnitude and composition of wealth and the reasons for them. On average, young black families hold 18 percent of the wealth of young white famliles, and hold thelr wealth in proportionately different forms. Even after controlling for racial differences in income and other demographic factors, as much as three-quarters of the wealth gap renains unexplained. We speculate on the causes for this, concluding that racial differences in intergenerational transfers most likely play an important role.

Francine D. Blau

Institute of Labor and Industrial Relations University of Illinois 504 East Armory Avenue Champaign, IL 61820
John W. Graham

Department of Economics

Rutgers University

360 Martin Luther King Blvd.

Newark, NJ 07102 
The purpose of this study is to examine racial differences in the magnitude and composition of wealth and to identify the reasons for these differences. We present recent cross-sectional data which show that, on average, young black fawilies hold only about 18 percent of the wealth of young white families and tend to hold this wealth in proportionately different forms. Blacks share a varlety of characteristics that may lower their net worth relative to whites, most especially their lower income, but also such demographic factors as a higher incidence of central city residence and famllies with single heads. We find that the income difference is the largest factor explaining racial differences in wealth, but that even after controlling for Income and other demographic factors, as much as three-quarters of the wealth gap remains. We speculate on the causes of these unexplained differences. An Investigation of wealth is important in formulating a more complete picture of racial differences in well-being. Most studies of economic wellbeing focus solely on income, but if wealth differences are greater than income differences, then these studies will underestimate racial inequality. Furthermore, if wealth differences exceed what could be expected on the basis of racial differences in incone, traditional policles which seek to narrow Income differences through labor market or transfer prograus will not be sufficlent to close the wealth gap. Finally, wealth differences are also of special concern because of their implications for intergenerational equity. If blacks today have less wealth than whites, their children are likely to have less as well to the extent that a substantial fraction of wealth is bequeathed or used to finance children's education.

Previous studies of raclal differences in wealth, although relatively sparse, find black to white wealth ratios ranging from 0.08 to 0.19 [Terrell, 
1971; Smith, 1975; Soltow, 1972; and Sobol, 1979]. In one of the few studles to investigate the causes of these differences, Terrell finds that racial differences in Income are not sufficlent to account for the observed wealth disparity: within the same income brackets black famflies have less than onehalf the wealth accumulation of white famllies. However, an important limitation of his study is that the effects of other variables are not controlled for. Studies of racial differences in asset composition are especially rare. Sobol [1979] finds that some assets such as net equity in a business are much more unequally distributed by race than other assets such as checking and savings accounts. However, her analysis is not conducted in such a way that It is possible to ascertain what factors might be responsible for these differences in asset composition.

The present study bullds on previous work by performing a much more comprehensive analysis of racial differences in wealth and asset composition, using data from the 1976 National Longltudinal Survey (NLS) of young men and the 1978 NLS of young women. Various evidence suggests that the period since the mid-1960's has been one of substantial improvement in the relative labor market success of black Americans, especially of younger blacks [Freeman, 1980; Brown, 1984]. Our sample of relatively young families (the mean age of the family heads is 30 ) focuses upon the group that has benefitted the wost from Improvements in the labor market, and nets out the effects of past discrimination and other disabilities which older blacks presumably suffered to a greater extent. Thus, evidence of large unexplained racial differentials in wealth for this relatively advantaged group of younger blacks would be of particular concern. Section II gives an overview of racial differences in wealth and asset composition for this group. The theoretical framework and methodology employed in analyzing these differences are detailed in Section III and our results are presented in Section IV. 
II. AN OVERVIEW OF RACIAL DIFFERENCES IN THE NLS

Separate data extracts from the NLS of young men and of young women were merged so as to increase the overall sample size and to include more household types (i.e., married-couple families, familles headed by single ${ }^{1}$ males or females, and one person households). In each survey the primary respondent was 24 to 34 years of age. ${ }^{2}$ The sample was restricted to families (or individuals) in which the respondent (or spouse) was the family head and nefther spouse was enrolled in school. Cases with missing data on any of the asset variables or other variables used in our regression analyses were excluded. ${ }^{3}$

We study wealth differences among married couples and households with single heads (including one person households) separately in order to control more fully for racial differences in household structure. Table I shows differences in wealth by race for married-couples, single heads, and the full sample. Wealth is defined as the sum of the value of net liquid assets, net business assets, equity in house(s), and equity in $\operatorname{car}(s) .^{4}$ All values are expressed in terms of 1976 dollars. As may be seen in Table $I$, the mean wealth of all black households is $\$ 4,177$, or 17.6 percent of the white mean of $\$ 23,703$.

Among both races, households with single heads hold less wealth than married couples. The higher incidence of households with single heads among blacks ( 45.3 percent) than among whites (23.4 percent) lowers their relative wealth. However, within each group, wealth differences remain quite large. Black mean wealth is 23 percent of the white mean among married couples and 13.5 percent among households with single heads. These wealth differences within each household type account for the major portion of the wealth differential in the full sample. That 1s, if blacks had the same incidence of each household type as whites but continued to differ in their mean levels of wealth, $\$ 18,544$ ( 95 percent) of the racial differential of $\$ 19,526$ would still 
remain. 5 Similarly, giving whites the black proportion of each household type would result in a continued differential of $\$ 16,406$ or 84 percent of the initial differential. 6 Thus, in the empirical work that follows we focus upon explaining the racial differences in wealth within each of the two groups.

The table also reveals some differences in asset composition by race. While blacks hold less of all assets than whites, they hold a higher proportion of their assets in the form of cars and houses, and a lower proportion in net liquid and net business assets. As in the case of the overall wealth differences, we seek to explain these differences in asset composition in terms of racial differences in family characteristics.

\section{THEORETICAL FRAMEWORK AND METHODOLOGY}

\section{A. Wea1th}

We now turn to the framework within which racial differences in wealth are analyzed. According to a standard 1ife cycle model [Modigliani and Brumberg, 1954], If $w_{0}$ is inherited wealth, $r$ is a fixed rate of interest, and $s_{1}$ is saving during period 1 , then the stock of wealth accumulated by the end of perlod $t$ can be defined as:

$$
w_{t}=w_{0}(1+r)^{t}+\sum_{i=1}^{t} s_{i}(1+r)^{t-1}
$$

In other words, wealth equals initial inheritance plus the sum of saving from all previous years, with interest compounded. Further, equation (1) suggests that differences in wealth across families at roughly the same stage of their Iffe cycle have three identifiable sources--differences in inheritance (or other Intergenerational transfers), rates of return, and saving behavior. Differences in saving, In turn, depend upon differences in lifetime (or permanent) Income, age and other socio-demographic factors related to tastes. 
Even in our relatively young sample, it is likely that all three of these factors play a role in explaining individual wealth differences, especially by race. First, while many of these families may not as yet have recelved substantial inheritances from their parents' estates, given current longevity and the typical age differences between generations, they are quite 1ikely to have recelved gifts or "intervivos" transfers in the form of, for example, money for college, a down payment on a house, or a share in a family-owned business. ${ }^{7}$ Second, given the 1mportance of "liquidity constraints" [Tobin, 1972], even young famliles are likely to have engaged in substantial amounts of past saving to accumulate wealth as a cushion against unanticipated fluctuations in their income. Finally, differential information or access to certain asset markets will cause ex ante rates of return to differ across families, and given unexpected capital gains or losses, ex poste returns may differ even more.

While the NLS data do not permit us to estimate equation (1) directly, they do allow us to do so indirectly by controlling for income and demographic factors that may be related to these three sources of wealth differences. To fully allow for behavioral differences by race, we estimate separate regressions for black and white familles. Specifically, for each household type (married couples and single heads) we estimate:

$$
w_{1 j}=a+b Y_{1 j}+c Z_{1 j}+e_{1 j}
$$

where $W_{1 j}$ equals wealth of famlly 1 of race $j\left(j=\right.$ black, white), $Y_{i j} 1$ s either the family's current observed income or a vector of 1 ts permanent and transitory income, $Z_{1 j}$ is a vector of socio-demographic characteristics, and $e_{1 j}$ is a normally-distributed error term. ${ }^{8}$ Variable definitions and sample means are provided in Table II.

The socio-demographic variables included in $Z$ are the age of the head of the household (AGEHEAD), family size (KIDS), location (CENTCITY, OTHSMSA, 
SOUTH), sex of the family head (FEMHEAD) for single heads, and weeks worked by the wife (WKSWRK-W) for married couples. We expect the coefficients on AGEHEAD and KIDS to be positive since older households will have had more time to save, and those with more children may have a higher propensity to do so. The location variables represent a variety of factors, including price levels and differential access to and/or demand for specific assets (especially housing) which might affect rates of return. Households headed by a woman only may have experfenced greater variation than other households in their economic circumstances--especially past income levels--and so may have accumulated less wealth, ceteris paribus. There is some evidence [Brown, 1979] that families with working-wives save less than other famflies at the same income level. This way be due to higher work-related expenses or a reduced precautionary demand for saving.

Current income, through its effect on saving, is expected to have a positive coefficient in a wealth regression, although the size of the coefficient may differ by race, as discussed below. Since current income may not be a very good proxy for the lifetime or permanent income upon which saving decisions are based, we also estimate wealth regressions with measures of permanent (PINC) and transitory (INCDIF) income estimated on the basis of family income regressions. 9 Both PINC and INCDIF are expected to have positive signs. However, since a given increment in INCDIF only represents higher income in the particular year, while an increment in PINC reflects higher Income over a number of periods, we expect the effect of PINC on wealth to be larger than the effect of INCDIF. The inclusion of a measure of permanent income is particularly important for blacks in that, given their higher unemployment rates, current income is likely to be a poorer indicator of their long-term income situation. Thus, while we have somewhat less confidence in the estimates of permanent income for single heads than for married couples, 
since the structure of the former households is more likely to change over time, we still consider the specification including PINC and INCDIF to be super1or.

\section{B. Portfollo Composition}

Modern portfollo theory (e.g., Baumol [1970]) suggests that families hold their wealth in a diversity of forms because assets differ in their percelved risk, liquidity, divisibility, and exclusivity of yleld. Consumer demand for broadly defined asset categorles (net liquid assets vs. home equity, for example) depends upon differences in tastes (1ncluding attitudes toward risktaking) and opportunities (expected rates of return). While none of these factors can be observed directly, it may be posslble to capture them indirectly by measures such as famfly income, age, wealth, and other socio-demographlc varlables. Th1s approach has been taken by Watts and Tobin [1960], Crockett and Friend [1967], and Shorrocks [1982] among others. None of these studies pays particular attention to race per se as a determinant of asset composition.

To separate the effect of race from other determinants of asset composition and to allow the 1mpact of race differ by asset, we estlmate separate regresslons (by race) for each of four asset categorles. We hypothesize that

$$
A_{k}=a_{k}+b_{k} Y+c_{k} z+d_{k} w+e_{k}, \quad k=1,[1, \ldots, 4]
$$

where $A_{k}$ equals holdings of asset $k$ (by the 1 th famlly of race $j$, where the 1 , $j$ subscripts have been omitted to simplify the notation) $Y$, and $Z$ have been defined above, and

$$
W=A_{1}+A_{2}+A_{3}+A_{4}
$$

where $A_{1}=$ net liquid assets, $A_{2}=$ net business assets, $A_{3}=$ equity in house(s), and $A_{4}=$ equity in car(s). The inclusion of total wealth itself as 
a determinant of net asset composition is meant to capture market imperfections such as differential access to credit across famllies at different levels of wealth and their unequal ability to acquire certain assets with large minimum denomination restrictions. 10

\section{Racial Differences}

In estimating equations (2) and (3), we allow for racial differences in the effect of income on wealth. We expect the coefficient on actual income to be smaller in the black wealth regressions. Since blacks have historically faced higher unemployment rates than whites (e.g., 14.0 percent vs. 6.4 percent in 1976), a given level of measured income is likely to have a higher transitory component and thus be a poorer indication of permanent income for blacks than whites. Thus, even if there are no racial differences in the wealth regression coefficients on permanent income, there will appear to be differences using actual income.

Once we control for raclal differences in permanent income and demographic factors, are there any a priori reasons to expect ceteris paribus racial differences in wealth and asset composition? There may be if expected future Income growth differs by race. For example, if blacks expect faster future income growth than whites, they may have saved less out of past income, thus lowering the ratio of current wealth to income. However, recent studies by Lazear [1979] and Smith and Welch [1986] find no racial differences in wage growth for males in our particular cohort. 11 other possible reasons for ceteris paribus raclal differences are suggested by equation (1).

First, black families will have less wealth than white families if they engage in proportionately less saving. However, Friedman [1957] cites several pieces of evidence (Pp. 79-85) which suggest that for a given income, blacks actually consume less and save more than whites. Alexis [1971] also finds 
support for the proposition that the saving rate of blacks exceeds that of whites. Galenson [1972] finds that black and white families in the 1960-61 Consumer Expenditure Survey (CES) exhibit 1dentical saving rates, while Hamermesh [1982], using data from the 1972-73 CES, finds that, out of a given Income, black's consumption expenditures are lower than white's. Thus, we are led to conclude that raclal differences in wealth, controlling for income and other factors, are not expected on the basis of differences in saving behavior.

Second, differences in Inheritance or other Intergenerational transfers may be a potential source of racial differences 1 wealth. While there is little direct information on Intergenerational transfers by race, Smith [1975] provides some relevant evidence by examining estate records for deceased persons in 1967 In Washington, D.C. He finds that mean black net worth for males was $\$ 9,654$, or less than one-s1xth of the mean white male net worth of $\$ 61,756$. Raclal differences in intergenerational transfers ( $W_{0}$ in equation (1)) are likely to be an 1mportant source of unexplained raclal differences in our wealth regressions because, given the labor market progress of younger blacks during the 1960s and 1970s, a black's family of origin 1s 11kely to have had lower income and wealth than that of a white with similar levels of our control variables. Intergenerational transfers may affect the composition as well as the level of wealth. Blacks may find 1 more difficult to purchase a home without a gift or low interest loan from their parents for the down payment. Similarly, to the extent that blacks are less likely to have Inherited property or a famlly business or farm, or to have the opportunity to join an on-going family enterprise, we may expect net business assets to comprise a smaller proportion of black wealth, all else equal. ${ }^{12}$ 
The final source of wealth differences according to equation (1) is differences in rates of return, both within and across asset categories. If blacks face barriers to acquiring certain assets such as housing and businesses which historically have pald among the highest real rates of return, they are likely to earn a lower overall return on their portfollos than do whites. In the case of business assets, blacks may face customer discrimination, difficulty in securing loans, or poor information about investment opportunities due to prior discrimination in education. While it is difficult to assess the Importance of such factors for business assets, there is a substantial literature on the effects of racial discrimination on home ownership. Controlling for income and demographic differences, there is clear evidence of racial differences in home ownership rates and housing values favoring whites (e.g., Kain and Quigley [1972]; Jackman and Jackman [1980]). However, these differences are much less pronounced among recent movers [Roistacher and Goodman, 1976], or controlling also for differences in total wealth [Birnbaum and Westin, 1974]. Indeed, this latter evidence suggests that housing market discrimination, although it may reduce total wealth, need not lower the proportion of wealth comprised of home equity. In fact, locational segregation and price discrimination could actually work to increase the share of home equity in black wealth, all else equal.

The labor market situation of blacks may also produce raclal differences In asset composition and hence in rates of returns. Higher unemployment and greater income uncertainty may increase the demand of blacks for liquid (relative to other types of) assets. Since rates of return are of ten lower for liquid assets than for other types, blacks may earn a lower overall return on their portfolio, particularly if they lack information about or access to higher ylelding liquid assets, such as stocks and bonds. 
v. EMPIRICAL RESULTS

\section{A. Wealth}

The wealth regression results for married couples and single heads are shown in Table III for specifications in which either current income (INCOME) or estimated permanent (PINC) and transitory (INCDIF) income are employed as explanatory variables. ${ }^{13}$ The results for the equations including PINC and INCDIF conform to expectations. The coefficients on PINC and INCDIF are consistently positive, with the coefficient on PINC greater than that on INCDIF. In addition, coefficients on PINC are larger than the corresponding coefficients on INCOME, suggesting that the former is indeed a better indicator of the long-term income position of the family. Within each household type, the difference in the coefficients on PINC and INCOME is relatively larger for blacks than whites, as would be expected given black's higher transitory income. Among married couples (single heads), the coefficient on PINC is 120 (98) percent higher than the INCOME coefficlent for blacks, compared to 45 (2) percent higher for whites. In the analysis which follows we focus on the specification which includes PINC and INCDIF, although the results are similar when the specification which includes INCOME is employed. ${ }^{14}$

As expected, the regression results indicate that for both races and household types, wealth tends to be positively related to AGEHEAD and KIDS, all else equal. Among married couples, WKSWRKW, CENTCITY, OTHSMSA and SOUTH are negatively related to wealth, although the effects are not always significant. Among households with single heads, FEMHEAD is negatively related to wealth, although not significantly, and, of the location variables, only one, CENTCITY, is significant in the white regressions with a negative sign.

The 1mpact of these factors on racial differentials may be illustrated with reference to Table II. Black households have lower permanent income, are 
more likely to live in the central city (but less likely to live in the suburbs), have a higher proportion of families headed by women only, and, among married couples, have wives who work a greater number of weeks on average--all characteristics associated with lower wealth. At the same time, as may be seen in Table III, the magnitude of the impact of these explanatory variables are often quite different in the black and white regressions. Most notable are the considerably smaller coefficients on PINC and AGEHEAD for blacks than for whites--64.5 (72) percent lower for PINC and 68.2 (94.1) percent lower for AGEHEAD anong married couples (single heads). ${ }^{15}$

In accounting for overall racial differences in wealth, we employ a standard means-coefficients analysis (e.g., see Blinder [1973]). The effect of race differences in means $(M)$ and coefficients (C) are computed as:

$$
\begin{aligned}
& M_{j}=\sum_{i}^{\sum B_{i j}}\left(\bar{x}_{i w}-\bar{X}_{i b}\right) \text { and } \\
& C_{j}=\sum_{i}^{\sum \bar{X}_{i j}}\left(B_{i w}-B_{i b}\right)
\end{aligned}
$$

where $B_{i j}$ and $\bar{x}_{1 j}$ are the estimated regression coefficient and mean of the ith explanatory variable for the $j$ th race group. Note that the estimate of the effect of the means (coefficients) may vary depending upon the weights chosen. In addition, the total differential (D) will be exhausted only by an inconsistent set of weights (an example of the index number problem). That is,

$$
D=\bar{W}_{w}-\bar{W}_{b}=M_{b}+C_{w}=M_{w}+C_{b} .
$$

In what follows, we use the term "unexplained differential" to refer to the differential that cannot be accounted for by race differences in the means of the explanatory variables, evaluated by the indicated (black or white) function. 
In general, the more dissimilar the two wealth functions, the greater the likellhood of obtalning very different results depending on the welghts employed. This is precisely the situation revealed in the decomposition of the raclal wealth differences shown in Table IV. Differences in the means of the explanatory variables are estimated to explain 73.6 (96.6) percent of the wealth differential for martied couples (single-heads) when the white functlons are used, but only about 22 percent when the black functions are employed. 16

Given the sharply differing results based on the black and white functions, it is reasonable to 1nquire whether there are any grounds for emphasizing one set of results over the other. While the selection of weights is in some sense arbitrary, it is also true that each comparison may be viewed as corresponding to a hypothetical situation or experiment. The results using the white functions indicate the consequences for the wealth gap of giving whites the black means. However, from a policy perspective, the more relevant question appears to be the one addressed when the black functions are employed: what would happen to black wealth if blacks were given the white means but retalned their own functions? The results indicate that even if we were successful in eliminating all the disadvantages of blacks in terms of their lower incomes and adverse locational and demographic characteristics, a large portion of the gap-78 percent--would remain. By this estimate, over threequarters of the observed racial differences in wealth appears to be related to race per se, as reflected in the dissimllar black and white wealth functions. Why are the black and white wealth functions so different? Indeed, the coefficient on permanent income alone is approximately three times as large in the white regressions as in the black. While some of the difference may be 
attributed to the effect of racial discrimination, we are probably already controlling for much of this by controlling for differences in family income and residential location. As we have seen, past studies appear to rule out major differences in the propensity to save as an explanation. In addition, while housing discrimination and other factors way produce race differences in rates of return, simulations with equation (1) suggest that differences in rates of return cannot explain more than a very small income coefficient difference. ${ }^{17}$ This leaves differences in inheritance and other intergenerational transfers as the most likely explanation. Thus, public policies that reduce such transfers (e.g., estate and gift taxes) may be the only way to equalize income coefficients--and thus eliminate most of the unexplained wealth differences.

The decomposition results for wealth are in sharp contrast to those obtained for income. As may be seen in Table IV, racial differentials in income are not only smaller than wealth differentials (In both absolute and relative terms), they are also more consistently explained by the characterIstics of black and white famllies. Differences in means are found to explain 62 to 84 percent of the Income gap among married couples, and 45 to 52 percent among famflies with single heads.

Given the overall effect of raclal differences in characteristics on the wealth gap, it is also of interest to ascertain the impact of various sets of variables taken separately. This information is presented in Table $V$. The various factors may influence wealth holdings both directly, controlling for Income, and Indirectly via their effect on Income itself. Thus, both direct and total (direct plus indirect) effects of each set of variables are shown in the table. 18

Considering first the direct effects, it may be seen that income is by far the most important factor in terms of Its impact on wealth, although its 
magnitude differs considerably depending upon which coefficients are used. Income differences between black and white families are estimated to account for approximately one quarter of the wealth differential based on the black functions and from 63.1 percent (married couples) to 90.6 percent (single heads) when the white functions are used. Controlling for income and other factors, racial. differences in wife's work status, incidence of female-headed families, and other demographic factors have relatively little impact on the wealth differential. The impact of locational factors is perhaps less than might be expected. Among married couples, residence has relatively little effect on the wealth gap because the negative effect of the greater tendency of blacks to live in central cities is approximately of fet by the greater tendency of whites to 11 ve in the suburbs. The continued greater tendency of blacks to be located in the South is estimated to explain 9.4 percent of the wealth difference among married couples when the white function is used. 19 Among single-heads, blacks' concentration in the central cities is found to adversely effect their wealth only when the white function is used, in which case it accounts for 15.7 percent of the wealth differential.

Looking at the total effects, we find that demographic factors ultimately play a larger role in explaining wealth differentials. Among the demographic variables, education is the most important, accounting for from 8.3 to 25.1 percent of the differential among martied couples and from 5.9 to 31.1 percent among single-heads. Somewhat greater effects of the residence variables are discerned among married couples, with thls factor accounting for as auch as 6.1 percent of the wealth gap when evaluated by the black function. The estimate of the contribution of Southern location is also somewhat increased.

The estimate of the unexplained portion of the wealth gap is raised when we focus on total effects because we include the Irapact of unexplained income 
as well as of unexplained wealth differences. Thus, approximately half of the wealth differential is not explained by raclal differences in the means of the explanatory variables, even when they are evaluated using the white functions. When the black functions are employed, the unexplained percentage ranges from 81.5 (married couples) to 93.2 (single heads).

\section{B. Asset Composition}

It may be recalled from Table I that blacks, on average, hold less of their wealth in the form of net liquid and net business assets and more in the form of equity in house(s) and car(s). In this section, we address the question of the extent to which this observed difference can be explained by differences in the means of the explanatory varlables. As in the preceding analysis of wealth differentials, a means-coefficlents decomposition is used to address this question. The results are shown in Table VI. 20

Agaln, the results are sensitive to the weighting scheme employed. Using the white functions, we find that racial differences in the means of the explanatory variables (including wealth) are more than sufficient to account for the observed differential in net liquid assets and that the unexplained differential is thus negative. This remains the case among single heads, but not among married couples, when the black functions are employed. Thus, while black families with single heads unambiguously hold a higher proportion ${ }^{21}$ of their wealth in the form of liquid assets than their white counterparts, among married couples this is only true at the lower levels of income and wealth represented by the black means.

Thus, we find some support for the expectation that blacks' higher unemployment rates (transitory income) result in their holding a higher proportion of their wealth in liquid form, particularly at lower levels of income and wealth. This is consistent with the holding of a minfmum cash reserve against 
the contingency of unemployment which, among married couples, increases less than in proportion to wealth with increasing affluence. It may also reflect a smaller utilization of more sophisticated forms of holding liquid assets (such as stocks and bonds) among married blacks relative to whites due, say, to poorer information about these options.

In the case of equity in house(s) (and, among married couples, car equity), we find that, at lower levels of income and wealth, blacks hold a smaller proportion of wealth in this form (these forms). However, if black married couples were given the higher levels of income and wealth represented by the white means, they would "overinvest" in housing (and cars) relative to whites, while the home equity and holdings of automobiles of black single-heads would be about the same as their white counterparts. Thus the evidence is not consistently supportive of the notion that housing discrimination lowers the proportion of wealth held by blacks in the form of housing. ${ }^{2}$ As noted above, it may well have other effects. While we control for residence in drawing this conclusion, it may readily be seen that racial differences in residence do not explain much of the racial differences in house equity when the black functions are employed.

At the white means, blacks are found to have a considerably smaller amount of net business assets than do whites. This is the case at the black means as well among single heads, although not among married couples. ${ }^{23}$ Thus some support is found for the possibility of barriers to the accumulation of business wealth among blacks, particularly at the higher levels of income and wealth represented by the white means. Indeed, a lack of opportunity to accumulate business wealth way in part explain the tendency of black married couples to hold a higher proportion of their wealth in the form of home equity (and cars) at the white means. 


\section{CONCLUSION}

In this paper we have examined black/white differences in wealth and asset composition among younger families. We have found large racial differences which cannot be explained by differences in income and other demographic and locational characteristics. Our findings suggest that even if policles designed to reduce racial differences in income and other differences in characteristics were completely successful, as much as three-quarters of the gap in wealth would remain. This large unexplained differential (due to differences in coefficients between black and white wealth functions) appears not to be primarily the result of racial differences in saving behavior or rates of return. Thus, we conclude that racial differences in inheritance and other intergenerational transfers most likely play an important role. Some support was also found for the possibility of barriers to the accumulation of business wealth among blacks. Thus, our findings suggest that additional policles which might help to lower the racial gap in wealth include increases in estate and gift taxes and the promotion of small businesses among blacks. 


\section{REFERENCES}

Alexis, Marcus, "Some Negro-White Differences in Consumption," The Black Consumer, George Joyce and Norman A. P. Govon1, eds. (New York: Random House, 1971), pp. 257-274.

Baumol, William J., Portfollo Theory: The Selection of Asset Combinations (New York: The McCaleb-Seller Publishing Company, 1970).

Birnbaum, Howard and Rafael Weston, "Howe Ownership and the Wealth Position of Black and White Americans," Review of Income and Wealth, XX (March 1974), 103-18.

Blinder, Alan S., "Wage Discrimination: Reduced Form and Structured Estimates," Journal of Human Resources, VIII (Fall 1973), 436-55.

Brainard, William and James Tobin, "Pitfalls in Financial Model Building," American Economic Review, LVIII (March 1968), 99-122.

Brown, Clair (Vickery), "Women's Economic Contribution to the Family," The Subtle Revolution, Ralph Smith, ed. (Washington, DC: The Urban Institute, 1979), PP. 159-200.

Brown, Charles, "Black-White Earnings Ratios Since the Civil Rights Act of 1964: The Importance of Labor Market Dropouts," Quarterly Journal of Economics, XCIX (February 1984), 31-44.

Crockett, Jean and Irwin Friend, "Consumer Investment Behavior," in Determinants of Investment Behavior, edited by Robert Ferber (New York: Columbia University Press, 1967).

Freeman, Richard B., "Black Economic Progress Post-1964: Who Ga1ned and Why?" Studies in Labor Markets, Sherwin Rosen, ed. (Chicago: The University of Chicago Press, 1980).

Friedman, Milton, A Theory of the Consumption Function (Princeton: Princeton University Press, 1957).

Galenson, Marjorie, "Do Blacks Save More?" American Economic Review, LXII (March 1972), 211-16.

Hamermesh, Daniel S., "Social Insurance and Consumption," American Economic Review, LXXII (March 1982), 101-113.

Jackman, Mary R. and Robert W. Jackman, "Raclal Inequalities in Home Ownership," Social Forces, LVIII (June 1980), 1221-1234.

Lazear, Edward, "The Narrowing of Black-White Wage Differentials is Illusory," LXIX (September 1979), 553-564.

Kain, John F. and John M. Quigley, "Housing Market Discrimination, Home Ownership, and Savings Behavior," American Economic Review 62 (June 1972), 263-77. 
Korlikoff, Laurence and Lawrence Summers, "The Role of Intergenerational Transfers in Aggregate Capttal Accumulation," Journal of Political Economy, LXXXIX (August 1981), 706-732.

Modigliani, Franco, "Measuring the Contribution of Intergenerational Transfers to Total Wealth: Conceptual Issues and Emplrical Findings," Seminar on Modeling the Accumulation and Distribution of Personal Wealth, Paris, 1984.

Modiglian1, Franco and Richard Brumberg, "Utflity Analysis and the Consumption Function: An Interpretation of Cross-Section Data," in Post-Keynesian Economics, edited by Kenneth K. Kurihara (New Brunswick, NJ: Rutgers University Press, 1954).

Frais, S. and H. Houthakker, The Analysis of Family Budgets (Cambridge: Cambridge University Press, 1955).

Roistacher, Elizabeth A. and John L. Goodman, Jr., "Race and Homeownership: Is Discrimination Disappearing?" Economic Inquiry, XIV (March 1976), 59-70.

Shorrocks, Anthony, "The Portfolio Composition of Asset Holdings in the United Kingdom," Economic Journal, LCII (June 1982), 268-284.

Smith, James D., "White Wealth and Black Pec-le: The Distribution of Wealth in Washington, D.C. In 1967," The Personal Distribution of Income and Wealth, James D. Smlth, ed. (New York: Columbia University Press, 1975).

Smith, James P, and Finis R. Welch, Closing the Gap: Forty Years of Economic Progress for Blacks (Santa Monica, CA: Rand Corporation, February 1986).

Sobol, Marion Gross, "Factors Influencing Private Capital Accumulation on the 'Eve of Retirement," Review of Economics and Statistics, LXI (November 1979), 585-593.

Soltow, Lee, "A Century of Personal Wealth Accumulation," The Economics of Black Amerlca, H. G. Vatter and T. Palm, eds. (New York: Harcourt Brace Jovanovich, 1972).

Terrell, Henry S., "Wealth Accumulation of Black and White Families: The Empirical Evidence," Journal of Finance (May 1971), 363-377.

Tobin, James, "Wealth, Liquidity, and the Propensity to Consume," in Human Behavior in Economic Affairs (Amsterdam: Elsevier, 1972).

Watts, Harold and James Tobin, "Consumer Expenditures and the Capital Account," in Consumption and Saving, edited by Irwin Friend and Robert C. Jones

(Philadelphia, 1960). 
1. For simplicity, we use the term single to refer to all respondents who are not married with a spouse present.

2. To keep the sample relatively homogeneous with respect to age, we required that the respondent's spouse be age 18 to 40 (if wives of male respondents) or 21 to 40 (if husbands of female respondents).

3. The proportion of cases remaining after exclusion for missing data was quite similar for whites and blacks (64 vs. 63 percent for married couples and 78 vs. 77 percent for single heads). Most exclusions were due to missing data on assets or income. The means of the remaining explanatory variables when cases with missing wealth or income are included are quite similar to those reported in Table II.

4. Cases with negative values of wealth or of particular assets are included in the analysis.

5. Computed as $\sum_{1=1}^{2} P_{W 1}\left(\bar{W}_{w 1}-\vec{W}_{b 1}\right)$, where $P_{1}=$ the proportion of the total comprised of the ith household type (1.e., married couples or single heads), $\bar{W}_{1}=$ the mean wealth of the 1 th household type, and the subscripts $w$ and $b$ refer to whites and blacks, respectively.

6. These calculations are intended to provide only a rough indication of the impact of family status on the racial wealth differential. If marriage is selective of the more economically advantaged, increasing the proportion of married couples among blacks may not lower the racial wealth differential by as much as our calculations suggest. Wealth levels may also be behaviorally related to marital status. On the one hand, the lower asset levels of black married couples may raise their probability of marital dissolution. On the other hand, to the extent that black couples anticipate a higher probability of marital break-up, they may have a lower incentive to accumulate assets.

7. There has been some recent debate over the fmportance of inheritance In aggregate analyses with Kotlikof $f$ and Summers [1981] concluding that inheritance represents an important source of aggregate wealth accumulation and Modigliani [1984] contending that its contribution to aggregate wealth is quite small.

8. Specifications of this type may suffer from heteroskedasticity (see, e.g., Prais and Houthakker [1955]). When heteroskedasticity is present, the OLS regression coefficients are unbiased although their conventionally calculated standard errors may be biased. Since our focus (see below) is on means-coefficients analyses of black-white differences in wealth and assets for which unbiased estimates of the regression coefficients are sufficient, we have not corrected for possible heteroskedasticity. Statements in the text regarding significance levels should, however, be interpreted with caution. 
9. The explanatory variables in the income regressions include age and age squared of head (and spouse), education and health of head (and spouse), as well as KIDS, CENTCITY, OTHSMSA, SOUTH and FEMHEAD (single-heads). Permanent income was set equal to predicted income evaluated at AGEHEAD equal to 30 . (The wife's age was set equal to what her age would be when her husband was 30.) This provides a consistent measure of permanent income that can be compared across familles which may be at somewhat different stages of the life cycle. Transitory income (INCDIF) is defined as the difference between observed income and predicted income evaluated at the actual age of the head (and wife).

10. Brafnard and Tobin [1968] have shown there are 1mportant crossequation restrictions that apply to the system of four equations in (3), specifically the coefficlents $a_{k}, b_{k}$, and $c_{k}$ wust each sum to zero across the four equations and the four coefficlents on wealth $\left(d_{k}\right)$ must sum to one. These restrictions are met by OLS estimation of ( 3 ).

11. Using longitudinal data frow the NLS, Lazear finds no significant race difference in wage growth over the 1966-69 period. Similarly, using Census data, Smith and Welch find that for the cohort with a median labor market entry of 1963 (1968), the black/white wage ratio was 70.1 (75.1) percent in 1970 and $71.2(73.5)$ percent in 1980. Published data from the Current Population Survey suggest that black and white women in this cohort also experienced similar wage growth. The ratic of black to white median income of full-t1me, year-round workers was 93.4 peicent among those aged 20-24 in 1970 and 95.6 percent among those aged 30-34 in 1980 .

12. Note that the value of access to a famlly business most likely exceeds the market value of the business itself. The individual is likely to have recelved informal training in the conduct of the business from his or her parents, as well as many useful contacts.

13. The sample sizes differ somewhat between the two specifications because those using INCOME as an explanatory variable exclude cases for which INCOME is negative, and include cases which have missing values for variables which are used to predict income but not wealth (e.g., EDUC-H, EDUC-W). The underlying income regressions used to estimate PINC and INCDIF are avallable f rom the authors upon request.

14. When the INCOME specification is employed, a smaller proportion of the differential is found to be explained by racial differences in the means of the explanatory variables (see below).

15. These differences are signiflcant at the 1 percent level in the case of married couples and at the 2 percent level in the case of single heads.

16. When the specification using actual income rather than PINC is employed, the mean effects are smaller. Expressed as percentages of the total differential, they are $M_{b}=19.4$ and $M_{w}=59.4$ (married couples) and $M_{b}=11.3$ and $M_{W}=89.4$ (single heads). When a PINC squared term is included in the permanent income specification to allow for possible nonlinearities in the relationship between income and wealth, the results are quite similar to those reported in the text. The coefficient on PINC squared is negative in all the 
regressions (but significant only in the case of white married couples). The mean effects (as a percent of the total differential) are $M_{b}=21.3$ and $M_{W}=83.9$ (married couples) and $M_{b}=21.0$ and $M_{W}=98.9$ (single heads).

17. Suppose that saving is identically $s$ percent of permanent income $\bar{Y}$ in each year; that is,

$$
s_{1}=s_{2}=\ldots=s_{t}=s \bar{Y} \text {. }
$$

This means that equation ( 1 ) can be rewritten as

$$
W_{t}=W_{0}(1+r)^{t}+s \bar{Y} \sum_{i=1}^{t}(1+r)^{t-1}=W_{0}(1+r)^{t}+s \bar{Y}\left[\frac{(1+r)^{t}-1}{r}\right]
$$

If $s$ is the same for white and black families, then the income coefficient differs only because of racial differences in $r$ (for a given date $t$ ). Assume that $s$ is 0.1 and $t=10$. If blacks earn $r=0.03$ on their portfolio, then their income coefficient would be 1.146, which is quite close to the coefficient on PINC for black married couples reported in Table III of 1.156 . However, even if whites earned $r=0.09--$ three times the black rate of return-their income coefficient would be only 1.519. Thus, for reasonable parameter values, it would appear that interest rate differences could not account for more than a small differential in the income coefficient.

18. The indirect effect of racial differences in the means of variable $X_{i}$ on wealth is

$$
I_{j}=B_{1 j}\left[B_{1 j}^{*}\left(\bar{X}_{i w}-\bar{X}_{1 b}\right)\right]
$$

where $B_{i j}^{*}$ is the coefficient on the ith explanatory variable for the $j$ th race group in the income regression and the other terms have been defined above.

19. The concentration of blacks in our sample in the South (see Table II) is higher than figures obtained from Census data which indicate that in 1980, about 56 percent of married and 48 percent of single (nonmarried) black men and women aged 25 to 39 lived in the South. This difference most likely results from the oversampling of households in predominantly black enumeration districts which was employed to increase the number of blacks in the sample. Adjustment for this factor would, however, have only a modest effect on the decomposition results reported above.

20. The regression results upon which these computations are based are available upon request.

21. Note that since the regressions control for total wealth, a dollar differential in favor of blacks implies that they hold a higher proportion of their wealth in this form.

22. Birnbaum and Weston [1974] find similar results for the probability of home ownership, controlling for wealth. At the black means, whites were more likely to own homes than blacks, however, at the white means, blacks were 
more likely to be homeowners. It might be argued that barriers to home ownership among blacks lower their wealth levels so that, controlling for wealth, the black disadvantage is not apparent. When similat calculations are performed based on regressions in which wealth is not included as an explanatory variable, it is found that house equity is indeed lower evaluated at both the white and black means. The unexplained differential ranged from 27.3 (black means) to 70.7 percent (white means) of the total differential among married couples and from 84.9 (black means) to 91.7 (white means) among single heads. However, among married couples, blacks would hold a higher proportion of their wealth in the form of housing, regardless of whether the functions are evaluated at the black or at the white means. The findings for the proportion of wealth held in house equity for single-heads remain the same as those reported in the text.

23. In this case, it is found that when wealth is omitted as an explanatory variable, blacks would hold a smaller proportion of their wealth in the form of business assets when the functions are evaluated at either the white or the black means. 
Table I

Wealth and Income by Race and Household Type

(1976 Dollars)

\begin{tabular}{|c|c|c|c|c|c|c|c|c|c|}
\hline & \multicolumn{3}{|c|}{ Married couples } & \multicolumn{3}{|c|}{ Single heads } & \multicolumn{3}{|c|}{ Total } \\
\hline & $\frac{\text { Black }}{(\$)}$ & $\frac{\text { White }}{(\$)}$ & $\frac{\operatorname{Rac10} 0^{b}}{(Z)}$ & $\frac{\text { Bl ack }}{(\$)}$ & $\frac{\text { Hhite }}{(\$)}$ & $\frac{\operatorname{Rat} 10^{b}}{(\bar{z})}$ & $\frac{\text { Black }}{(\$)}$ & $\frac{\text { White }}{(\$)}$ & $\frac{\operatorname{Rat} 10^{b}}{(z)}$ \\
\hline $\begin{array}{l}\text { Net } \\
\text { Liquid }\end{array}$ & & & & & & & & & \\
\hline Assets & -74 & 2,756 & -2.7 & 246 & 3,604 & 6.8 & 71 & 2,955 & 2.4 \\
\hline Net & & & & & & & & & \\
\hline $\begin{array}{l}\text { Business } \\
\text { Assets }\end{array}$ & 569 & 7,874 & 7.2 & 281 & 4,793 & 5.9 & 438 & 7,152 & 6.1 \\
\hline $\begin{array}{l}\text { Equity } \\
\text { In }\end{array}$ & & & & & & & & & \\
\hline House (s) & 4,222 & 13,864 & 30.5 & 665 & 2,616 & 25.4 & 2,610 & 11,230 & 23.2 \\
\hline $\begin{array}{l}\text { Equity } \\
\text { In }\end{array}$ & & & & & & & & & \\
\hline $\operatorname{Car}(6)$ & 1,492 & 2,544 & 58.6 & 533 & 1,782 & 29.9 & 1,057 & 2,366 & 44.7 \\
\hline Wealth & 6,210 & 27,039 & 23.0 & 1,725 & 12,795 & 13.5 & 4,177 & 23,703 & 17.6 \\
\hline Income & 13,304 & 17,636 & 75.4 & 6,783 & 10,418 & 65.1 & 10,349 & 15,946 & 64.9 \\
\hline $\begin{array}{l}\text { Number } \\
\text { of } \\
\text { Obser- } \\
\text { vations }\end{array}$ & 485 & 2,204 & & 402 & 674 & & 887 & 2,878 & \\
\hline
\end{tabular}

a. Net liquid assets consist of checking and savings accounts, U.S. savings bonds, stocks and bonds and mutual funds, and personal loans to friends and relatives, less other debts. Other debts are defined as the value of all liablities other than those against business, house or cars. Net business assets equal the market value of farm, business and real estate assets minus autstanding liablities on such assets. Equity in house(s) equals the market value of owneraccupled housing minus the value of the unpaid mortgage. Equity in cars equals the market value of cars owned winus the value of outstanding loans on those cars.

b. The black mean divided by the white mean. 
Table Ir

Means of Explanatory Variables By Race (standard deviations)

\begin{tabular}{|c|c|c|c|c|}
\hline & \multicolumn{2}{|c|}{ Married couples } & \multicolumn{2}{|c|}{ Single heads } \\
\hline & Black & White & Black & White \\
\hline AGEHEAD = age of head & $\begin{array}{l}29.73 \\
(3.64)\end{array}$ & $\begin{array}{l}30.08 \\
(3.73)\end{array}$ & $\begin{array}{l}28.35 \\
(3.20)\end{array}$ & $\begin{array}{l}27.86 \\
(2.97)\end{array}$ \\
\hline $\begin{array}{l}\text { FEMGEAD = } 1 \text { if head is a single } \\
\text { woman; and } 0 \text { otherwise }\end{array}$ & $\cdots$ & $\cdots$ & $\begin{array}{l}.67 \\
(.47)\end{array}$ & $(.49$ \\
\hline KIDS $=$ number of children & $\begin{array}{c}2.06 \\
(1.56)\end{array}$ & $\begin{array}{l}1.59 \\
(1.19)\end{array}$ & $\begin{array}{c}1.43 \\
(1.64)\end{array}$ & $\begin{array}{l}.44 \\
(.90)\end{array}$ \\
\hline $\begin{array}{l}\text { WRSWRK-W = weeks worked of } \\
\text { wife }\end{array}$ & $\begin{array}{c}29.46 \\
(22.08)\end{array}$ & $\begin{array}{l}24.46 \\
(22.53)\end{array}$ & $\cdots$ & $\cdots$ \\
\hline $\begin{array}{l}\text { CENTCITY = } 1 \text { if resides in } \\
\text { central city; and } 0 \text { otherwise }\end{array}$ & $\begin{array}{l}.49 \\
\end{array}$ & $(.22)$ & $\begin{array}{l}.65 \\
(.48)\end{array}$ & $\begin{array}{l}.39 \\
(.49)\end{array}$ \\
\hline $\begin{array}{l}\text { OTHSMSA }=1 \text { if resides in SMSA } \\
\text { outside central city; and } \\
0 \text { otherwise }\end{array}$ & $\begin{array}{l}.16 \\
(.37)\end{array}$ & $\begin{array}{l}.44 \\
. .50)\end{array}$ & $\begin{array}{l}.18 \\
(.38)\end{array}$ & $(.38)$ \\
\hline $\begin{array}{l}\text { SOUTH }=1 \text { if resides in the } \\
\text { South; and } 0 \text { otherwise }\end{array}$ & $\begin{array}{l}.72 \\
(.45)\end{array}$ & $\begin{array}{l}.31 \\
(.46)\end{array}$ & $\begin{array}{l}.50 \\
(.50)\end{array}$ & $\begin{array}{l}.28 \\
(.45)\end{array}$ \\
\hline $\begin{array}{l}\operatorname{INCOME}\left(1000^{\prime} s\right)=\text { actual } \\
\text { income }\end{array}$ & $\begin{array}{l}13.30 \\
(7.47)\end{array}$ & $\begin{array}{l}17.64 \\
(8.54)\end{array}$ & $\begin{array}{c}6.78 \\
(5.14)\end{array}$ & $\begin{array}{l}10.42 \\
(6.75)\end{array}$ \\
\hline $\begin{array}{l}\text { PINC }\left(1000^{\prime} s\right) \text { estimated } \\
\text { permanent income at } \\
A G E H E A D=30\end{array}$ & $\begin{array}{l}13.71 \\
(4.13)\end{array}$ & $\begin{array}{l}17.78 \\
(3.50)\end{array}$ & $\begin{array}{l}7.18 \\
(1.78)\end{array}$ & $\begin{array}{l}11.34 \\
(2.75)\end{array}$ \\
\hline AGEWIFE = age of wife & $\begin{array}{l}27.78 \\
(3.64)\end{array}$ & $\begin{array}{l}28.26 \\
(3.57)\end{array}$ & -.. & $\cdots$ \\
\hline $\begin{array}{l}\text { EDUC-H = years of school } \\
\text { completed by head }\end{array}$ & $\begin{array}{l}11.52 \\
(2.81)\end{array}$ & $\begin{array}{l}13.21 \\
(2.67)\end{array}$ & $\begin{array}{l}11.47 \\
(2.71)\end{array}$ & $\begin{array}{l}13.69 \\
(2.68)\end{array}$ \\
\hline $\begin{array}{l}\text { EDUC-W = years of school } \\
\text { completed by wife }\end{array}$ & $\begin{array}{l}11.61 \\
(2.48)\end{array}$ & $\begin{array}{l}12.67 \\
(2.38)\end{array}$ & -.. & $\cdots$ \\
\hline Number of observations & 485 & 2,204 & 402 & 674 \\
\hline
\end{tabular}


Table III

Regreasion Results: Wealth

(standard errors)

\begin{tabular}{|c|c|c|c|c|c|c|c|c|}
\hline \multirow{3}{*}{$\begin{array}{l}\text { Explanatory } \\
\text { Veriables }\end{array}$} & \multicolumn{4}{|c|}{ Married couples } & \multicolumn{4}{|c|}{ Single heads } \\
\hline & & Blacks & & Ifes & & k.6 & $=0$ & $\overline{\text { hites }}$ \\
\hline & (1) & (2) & (1) & (2) & (1) & (2) & (1) & (2) \\
\hline $\begin{array}{l}\text { Incoee } \\
\left(1000^{\prime} 8\right)\end{array}$ & $\begin{array}{l}525 * \\
(73)\end{array}$ & $\cdots$ & $\begin{array}{c}2,229 * k \\
(132)\end{array}$ & $\cdots$ & $\begin{array}{l}340 * * \\
(73)\end{array}$ & $\cdots$ & $\begin{array}{c}2,353 * * \\
(247)\end{array}$ & $\cdots$ \\
\hline $\begin{array}{l}\text { PINC } \\
\left(1000^{\prime} 8\right)\end{array}$ & $\cdots$ & $\begin{array}{l}1,156 * * \\
(157)\end{array}$ & $\cdots$ & $\begin{array}{c}3,229 k * \\
(400)\end{array}$ & $\cdots$ & $\begin{array}{l}672 * \\
(312)\end{array}$ & $\cdots$ & $\begin{array}{c}2,408 * * \\
(901)\end{array}$ \\
\hline $\begin{array}{l}\text { INCDIF } \\
\left(1000^{\prime} \mathrm{s}\right)\end{array}$ & $\ldots$ & $\begin{array}{l}353 * * \\
(71)\end{array}$ & $\cdots$ & $\begin{array}{c}1,862 * * \\
(149)\end{array}$ & ... & $\begin{array}{l}319 * * \\
(73)\end{array}$ & ... & $\begin{array}{c}2,264 * * \\
(251)\end{array}$ \\
\hline AGEHEAD & $\begin{array}{l}456^{*} \\
(123)\end{array}$ & $\begin{array}{l}795 * \\
(117)\end{array}$ & $\begin{array}{l}971 * \text { * } \\
(312)\end{array}$ & $\begin{array}{l}2,497 * * \\
(321)\end{array}$ & $\begin{array}{c}47 \\
(117)\end{array}$ & $\begin{array}{c}83 \\
(116)\end{array}$ & $\begin{array}{c}296 \\
(565)\end{array}$ & $\begin{array}{r}1,409 \\
(547)\end{array}$ \\
\hline KIDS & $\begin{array}{c}124 \\
(322)\end{array}$ & $\begin{array}{r}683^{*} \\
(314)\end{array}$ & $\begin{array}{c}1,370 \\
(1,008)\end{array}$ & $\begin{array}{c}2,803 \star \\
(1,159)\end{array}$ & $\begin{array}{c}-30 \\
(281)\end{array}$ & $\begin{array}{c}28 \\
(284)\end{array}$ & $\begin{array}{c}184 \\
(1,964)\end{array}$ & $\begin{array}{c}269 \\
(2,127)\end{array}$ \\
\hline PEYHEAD & $\cdots$ & $\cdots$ & $\cdots$ & $\ldots$ & $\begin{array}{r}-1,380 \\
(978)\end{array}$ & $\begin{array}{c}-979 \\
(1,004)\end{array}$ & $\begin{array}{c}-744 \\
(3,458)\end{array}$ & $\begin{array}{c}-883 \\
(4,259)\end{array}$ \\
\hline WRSWRKW & $\begin{array}{l}-15 \\
(23)\end{array}$ & $\begin{array}{c}-9 \\
(22)\end{array}$ & $\begin{array}{c}-184 \star \star \\
(50)\end{array}$ & $\begin{array}{l}-164 * k \\
(54)\end{array}$ & $\ldots$ & ... & $\cdots$ & $\ldots$ \\
\hline CENTCITY & $\begin{array}{l}-3,711 \text { t } \\
(1,124)\end{array}$ & $\begin{array}{l}-5,322 * * \\
(1,093)\end{array}$ & $\begin{array}{l}-5,578 \\
(2,280)\end{array}$ & $\begin{array}{l}-8,364 \star \\
(3,163)\end{array}$ & $\begin{array}{c}826 \\
(1,045)\end{array}$ & $\begin{array}{c}542 \\
(1,063)\end{array}$ & $\begin{array}{r}-10,068 * \\
(4,113)\end{array}$ & $\begin{array}{r}-10,100 * \\
(4,496)\end{array}$ \\
\hline OTHSKSA & $\begin{array}{c}711 \\
(1,503)\end{array}$ & $\begin{array}{l}-3,855 * \\
(1,587)\end{array}$ & $\begin{array}{l}-5,681 \\
(2,464)\end{array}$ & $\begin{array}{l}-8,606 * * \\
(2,813)\end{array}$ & $\begin{array}{c}-101 \\
(1,270)\end{array}$ & $\begin{array}{c}-792 \\
(1.409)\end{array}$ & $\begin{array}{l}-4,360 \\
(4,085)\end{array}$ & $\begin{array}{l}-4,749 \\
(4,294)\end{array}$ \\
\hline souTH & $\begin{array}{c}-879 \\
(1,157)\end{array}$ & $\begin{array}{l}1,262 \\
(1,110)\end{array}$ & $\begin{array}{l}-5,160 \star \\
(2,288)\end{array}$ & $\begin{array}{l}-4,698 \\
(2,486)\end{array}$ & $\begin{array}{l}110 \\
(777)\end{array}$ & $\begin{array}{c}779 \\
(972)\end{array}$ & $\begin{array}{c}1,388 \\
(3,441)\end{array}$ & $\begin{array}{c}1,229 \\
(3,439)\end{array}$ \\
\hline CONSTANT & $\begin{array}{c}-11,595 * k \\
(3,630)\end{array}$ & $\begin{array}{c}-32,079 * k \\
(4,543)\end{array}$ & $\begin{array}{c}-34,397 * \\
(8,909)\end{array}$ & $\begin{array}{l}-98,833 * \\
(12,174)\end{array}$ & $\begin{array}{l}-1,520 \\
(3,491)\end{array}$ & $\begin{array}{l}-5,448 \\
(4,302)\end{array}$ & $\begin{array}{l}-14,738 \\
(15,410)\end{array}$ & $\begin{array}{l}-48,098 * k \\
(17,964)\end{array}$ \\
\hline $\begin{array}{l}\mathrm{R}^{2} \\
\text { NOBS }\end{array}$ & $\begin{array}{r}18.4 \\
505\end{array}$ & $\begin{array}{r}22.0 \\
485\end{array}$ & $\begin{array}{r}13.9 \\
2,302\end{array}$ & $\begin{array}{r}12.0 \\
2,204\end{array}$ & $\begin{array}{l}7.0 \\
397\end{array}$ & $\begin{array}{l}7.2 \\
402\end{array}$ & $\begin{array}{r}14.0 \\
669\end{array}$ & $\begin{array}{r}13.6 \\
674\end{array}$ \\
\hline
\end{tabular}

- Coefficient is agnificant at the $S$ percent level on a two-tailed test.

* Coefficient is ignificant at the 1 percent level on two-talled test. 
I. Married couples

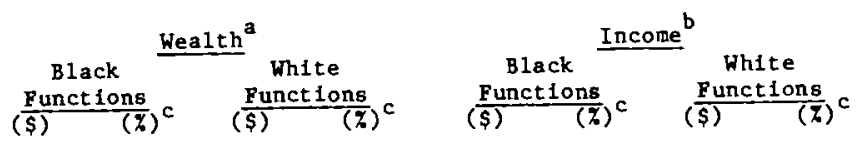

\begin{tabular}{|c|c|c|c|c|c|c|c|c|c|}
\hline (1) & $\begin{array}{l}\text { Evaluated at } \\
\text { black means }\end{array}$ & 6,210 & 23.0 & 11,704 & 43.1 & 13,304 & 75.4 & 14,950 & 84.8 \\
\hline (2) & $\begin{array}{l}\text { Evaluated at } \\
\text { white means }\end{array}$ & 10,755 & 39.8 & 27,039 & 100.0 & 16,937 & 96.0 & 17,636 & 100.0 \\
\hline (3) & $\begin{array}{l}\text { Unadjusted } \\
\text { differential }\end{array}$ & 20,829 & 77.0 & 20,829 & 77.0 & 4,332 & 24.6 & 4,332 & 24.6 \\
\hline (4) & $\begin{array}{l}\text { Explained }(2)-(1) \\
(\% \text { of unadjusted })\end{array}$ & 4,545 & $\begin{array}{l}16.8 \\
(21.8)\end{array}$ & 15,335 & $\begin{array}{c}56.7 \\
(73.6)\end{array}$ & 3,633 & $\begin{array}{c}20.6 \\
(83.9)\end{array}$ & 2,686 & $\begin{array}{l}15.2 \\
(62.0)\end{array}$ \\
\hline (5) & $\begin{array}{l}\text { Unexplained }(3)-(4) \\
(z \text { of unadjusted) }\end{array}$ & 16,284 & $\begin{array}{c}60.2 \\
(78.2)\end{array}$ & 5,494 & $\begin{array}{c}30.3 \\
(26.4)\end{array}$ & 699 & $\begin{array}{c}4.0 \\
(16.1)\end{array}$ & 1,646 & $\begin{array}{c}9.3 \\
(38.0)\end{array}$ \\
\hline
\end{tabular}

II. Single heads

(1) Evaluated at black means

(2) Evaluated at white means

(3) Unadjusted differential

(4) Explained (2)-(1) ( $\bar{z}$ of unadjusted)

(5) Unexplained (3)-(4) ( $\%$ of unadjusted)

$\begin{array}{rrrrrrrr}1,725 & 13.5 & 2,096 & 16.4 & 6,783 & 65.1 & 8,531 & 81.9 \\ 4,153 & 32.5 & 12,795 & 100.0 & 8,414 & 80.8 & 10,418 & 100.0 \\ & & & & & & & \\ 11,070 & 86.5 & 11,070 & 86.5 & 3,636 & 34.9 & 3,636 & 34.9 \\ 2,428 & 19.0 & 10,699 & 83.6 & 1,631 & 15.7 & 1,877 & 18.1 \\ & (21.9) & & (96.6) & & (44.9) & & (51.9) \\ 8,642 & \begin{array}{c}67.5 \\ (78.1)\end{array} & 371 & \begin{array}{c}2.9 \\ (3.4)\end{array} & 2,004 & 19.2 & 1,748 & 16.8 \\ & & & & (55.1) & & (48.1)\end{array}$

a. Based on wealth regressions reported in Table III.

b. Based on famlly income regressions avallable from the authors upon request.

c. As a percentage of the white mean. 
Table V

Decomposition of Racial Differences in Wealth: Direct and Total Effects

I. Married couples

Direct Effects
$\begin{gathered}\text { Black } \\ \text { Functions } \\ (\$)\end{gathered}$

Total Effects

Black White

$\frac{\text { Functions }}{(\$)}(\overline{\%})^{a} \quad(\$) \quad(\bar{x})$ a

\begin{tabular}{|c|c|c|c|c|c|c|c|c|}
\hline Explained Differential & 4,545 & 21.8 & 15,335 & 73.6 & 3,850 & 18.5 & 10,036 & 48.2 \\
\hline $\begin{array}{l}\text { Demographic } \\
\text { Characteristics }\end{array}$ & 3 & 0.0 & 374 & 1.8 & 2,127 & 10.2 & 6,828 & 32.8 \\
\hline Education & -- & -- & --- & -- & 1,723 & 8.3 & 5,234 & 25.1 \\
\hline Wife Work & 45 & 0.2 & 820 & 3.9 & 45 & 0.2 & 820 & 3.9 \\
\hline Residence & 359 & 1.7 & -141 & -0.7 & 1,275 & 6.1 & 345 & 1.7 \\
\hline Region & -524 & -2.5 & 1,951 & 9.4 & 448 & 2.2 & 2,863 & 13.7 \\
\hline Income & 4,707 & 22.6 & 13,150 & 63.1 & -- & - & $--\infty$ & - \\
\hline Unexplained Differential & 16,284 & 78.2 & 5,494 & 26.4 & 16,979 & $81 \cdot 5$ & 10,793 & 51.8 \\
\hline $\begin{array}{l}\text { Unexplained Income } \\
\text { Difference }\end{array}$ & --- & -- & -- & 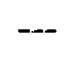 & 695 & 3.3 & 5,299 & 25.4 \\
\hline Total Different & 20,829 & 100.0 & 20,829 & 100.0 & 20,829 & 100.0 & 20,829 & 100.0 \\
\hline
\end{tabular}

II. Single heads

$\begin{array}{lllllllll}\text { Explained Differential } & 2,428 & 21.9 & 10,699 & 96.6 & 758 & 6.8 & 5,778 & 52.2\end{array}$

\begin{tabular}{|c|c|c|c|c|c|c|c|c|}
\hline $\begin{array}{l}\text { Demographic } \\
\text { Characteristics }\end{array}$ & 113 & 1.0 & -783 & $-7 \cdot 1$ & 872 & 7.9 & 4,571 & 41.3 \\
\hline Education & -- & -- & --- & -- & 650 & 5.9 & 3,438 & 31.1 \\
\hline Female Head & 181 & 1.6 & 163 & 1.5 & 330 & 3.0 & 1,454 & 13.1 \\
\hline Residence & -305 & -2.8 & 1,736 & 15.7 & -191 & -1.7 & 1,379 & 12.5 \\
\hline Region & -176 & -1.6 & -279 & -2.5 & 77 & 0.7 & -172 & -1.6 \\
\hline Income & 2,796 & 25.3 & 10,024 & 90.6 & $-\infty$ & --- & $\cdots-$ & -- \\
\hline xplalned Differential & 8,642 & 78.1 & 371 & 3.4 & 10,312 & 93.2 & 5,292 & 47.8 \\
\hline $\begin{array}{l}\text { Unexplained Income } \\
\text { Difference }\end{array}$ & -- & -- & $-\cdots$ & -- & 1,670 & 15.1 & 4,921 & 44.5 \\
\hline 1 Different 1 al & 11,070 & 100.0 & 11,070 & 100.0 & 11,070 & 100.0 & 11,070 & 100.0 \\
\hline
\end{tabular}

a. As a percentage of the total differential. 
Table VI

Decomposition of Racial Differences in Asset Composition

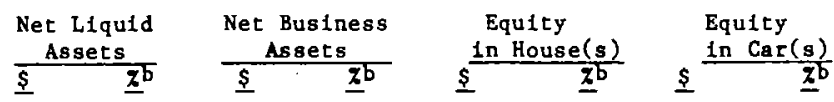

I. Married couples

$\begin{array}{lllllllll}\text { Total Differential } & 2,830 & 100.0 & 7,305 & 100.0 & 9,642 & 100.0 & 1,052 & 100.0\end{array}$

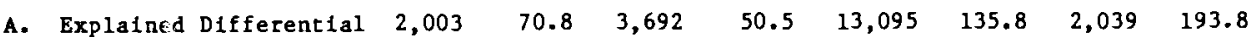
(black functions)

\begin{tabular}{|c|c|c|c|c|c|c|c|c|}
\hline $\begin{array}{l}\text { Demographic } \\
\text { Characteristics }\end{array}$ & 59 & 2.1 & 35 & 0.5 & -205 & -2.1 & 111 & 10.6 \\
\hline Resldence & 135 & 4.8 & -194 & -2.7 & 0 & 0.0 & 59 & 5.6 \\
\hline Reglon & 213 & 7.5 & -156 & -2.1 & -41 & -0.4 & -23 & -2.2 \\
\hline Income & -55 & -1.9 & -117 & -1.6 & 205 & 2.1 & -34 & -3.2 \\
\hline Wealth & 1,651 & 58.3 & 4,117 & 56.4 & 13,135 & 136.2 & 1,926 & 183.1 \\
\hline $\begin{array}{l}\text { Unexplained Differential } \\
\text { (wh1te tieans) }\end{array}$ & 827 & 29.2 & 3,614 & 49.5 & $-3,453$ & -35.8 & -988 & -93.9 \\
\hline $\begin{array}{l}\text { Explaired Differential } \\
\text { (whlte Functions) }\end{array}$ & 3,754 & 132.7 & 8,350 & 114.3 & 8,160 & 84.6 & 565 & 53.7 \\
\hline $\begin{array}{l}\text { Demoriraphlc } \\
\text { Charenteristics }\end{array}$ & 354 & 12.5 & -370 & -5.1 & -102 & $-1 \cdot 1$ & 117 & 11.1 \\
\hline Reslonce & -516 & -18.2 & -28 & -0.4 & 561 & 5.8 & -17 & -1.6 \\
\hline $\operatorname{Reg} 1$ (n) & -98 & -3.1 & $-1,241$ & -17.0 & 1,346 & 14.0 & -17 & -1.6 \\
\hline Inco. $?$ & 1,958 & 69.2 & $-4,159$ & -56.9 & 1,981 & 20.5 & 220 & 20.9 \\
\hline Wealiti & 2,047 & 72.3 & 14,147 & 193.7 & 4,374 & 45.4 & 261 & 24.8 \\
\hline $\begin{array}{l}\text { Unexplained Differential } \\
\text { (black means) }\end{array}$ & $1-924$ & -32.7 & $-1,045$ & $-14 \cdot 3$ & 1,482 & 15.4 & 487 & 46.3 \\
\hline
\end{tabular}


Table VI (cont'd.)

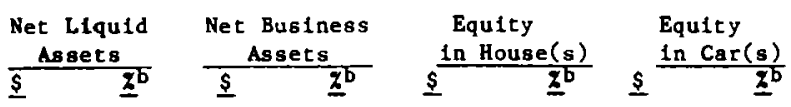

II. S1ngle heads

$\begin{array}{lllllllll}\text { Total Differential } & 3,358 & 100.0 & 4,513 & 100.0 & 1,951 & 100.0 & 1,249 & 100.0\end{array}$

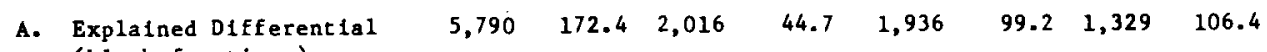

(black functions)

\begin{tabular}{|c|c|c|c|c|c|c|c|c|}
\hline $\begin{array}{l}\text { Denographlc } \\
\text { Characteristics }\end{array}$ & 199 & 5.9 & -69 & -1.5 & -218 & -11.2 & 87 & 7.0 \\
\hline Residence & 40 & 1.2 & -136 & -3.0 & 42 & 2.2 & 53 & 4.2 \\
\hline Region & 270 & 8.0 & -189 & -4.2 & -74 & -3.8 & -7 & -0.6 \\
\hline Income & $-1,470$ & -43.8 & 1,012 & 22.4 & -87 & -4.5 & 545 & 43.6 \\
\hline Wealth & 6,750 & 201.0 & 1,398 & 31.0 & 2,271 & 116.4 & 651 & 52.1 \\
\hline $\begin{array}{l}\text { hexplatned Differential } \\
\text { hite means) }\end{array}$ & $-2,432$ & -72.4 & 2,497 & 55.3 & 15 & 0.7 & -80 & 4 \\
\hline
\end{tabular}

\begin{tabular}{|c|c|c|c|c|c|c|c|c|}
\hline $\begin{array}{l}\text { B. Explained Differential } \\
\text { (white functions) }\end{array}$ & 5,859 & 174.5 & 3,732 & 82.7 & 322 & 16.5 & 1,156 & 92.6 \\
\hline $\begin{array}{l}\text { Demographlc } \\
\text { Characterlstics }\end{array}$ & -639 & -19.0 & 1,852 & 41.0 & $-1,579$ & -80.9 & 366 & 29.3 \\
\hline Res1dence & -125 & -3.7 & -212 & -4.7 & 334 & 17.1 & 2 & 0.2 \\
\hline Region & -412 & -12.3 & 160 & 3.5 & 157 & 8.0 & 95 & 7.6 \\
\hline Income & 2,283 & 68.0 & $-3,211$ & -71.2 & 567 & 29.1 & 362 & 29.0 \\
\hline Wealth & 4,753 & 141.5 & 5,144 & 114.0 & 842 & 43.2 & 330 & 26.4 \\
\hline $\begin{array}{l}\text { Unexpla1ned Differential } \\
\text { (black means) }\end{array}$ & $-2,502$ & -74.5 & 780 & 17.3 & 1,628 & 83.4 & 93 & 7.4 \\
\hline
\end{tabular}

a. Based on asset regressions avallable from the authors upon request.

b. As a percentage of total differential. 
Table A-I

Regression Results: Income (standard errors)

Explanatory

Variables

AGEHEAD

AGEHEAD $^{2}$

AGEWIFE

AGEWIFE $^{2}$

KIDS

FEMHEAD

EDUC-H

EDUC-W

HEALTH-H

HEALTH-W

CENTCITY

OTHSMSA

SOUTH

CONSTANT

$\mathrm{R}^{2}$

NOBS
Married couples Blacks

796
$(1,022)$

$-10$

(17)

2,173*

(929)

-34 *

(16)

$-505 *$

(209)

...

543* *

(122)

539**

(140)

$-1,797$

$(1,191)$

$-2,206 \star$
$(957)$

1,340

(712)

$4,155 *$ *

(938)

$-2,025 * \star$

(713)

$-46,675 *$ *

$(17,501)$

31.4

485
Whites

1,237

(672)

$-14$

(11)

232

(598)

1
$(10)$

$-687 \star \star$

(161)

..

$777 \star \star$

(76)

$286 * \alpha$

(86)

$-1,692 \star \star$
$(595)$

$-2,041$ *ᄎ

(611)

1,760 **

(448)

2,247 *

(379)

$-680$

(359)

$-27,260 *$

$(10,974)$

20.6

2,204
Single heads

Blacks

Whites

1,348

$-15$

$(1,530)$

$(1,555)$

$-21$

(26)

8
$(27)$

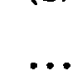

96
$(201)$

$-199$

(323)

$-1,195$

(661)

$-2,897$ *

(520)

$437 * \star$

(100)

$644 \star \star$

(98)

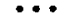

$-973$

(764)

$-1,751^{*}$

(854)

355
$(729)$

1,554 *

(632)

1,309

(889)

1,319 *

(627)

$-195$

(531)

(522)

$-3,939$

$(22,091)$

$(22,046)$

12.2

18.3

402

674

*Coefficient is significant at the 5 percent level on a two-talled test.

**Coefficient is significant at the 1 percent level on a two-tailed test. 
Table A-II

Regression Results for Assets, Married Couples (standard errors)

\begin{tabular}{|c|c|c|c|c|c|c|c|c|}
\hline \multirow[b]{2}{*}{$\begin{array}{l}\text { Explanatory } \\
\text { Variables } \\
\end{array}$} & \multicolumn{4}{|c|}{ Blacks $(N=485)$} & \multicolumn{4}{|c|}{ Whites $(N=2,204)$} \\
\hline & $\begin{array}{l}\text { Net } \\
\text { L1qu1d } \\
\text { Asset } 8 \\
\end{array}$ & $\begin{array}{c}\text { Net } \\
\text { Business } \\
\text { Assets } \\
\end{array}$ & $\begin{array}{c}\text { Equity } \\
\text { In } \\
\text { House (s) } \\
\end{array}$ & $\begin{array}{c}\text { Equity } \\
\operatorname{In} \\
\operatorname{Car}(\mathrm{s}) \\
\end{array}$ & $\begin{array}{c}\text { Net } \\
\text { Liquid } \\
\text { Assets } \\
\end{array}$ & $\begin{array}{c}\text { Net } \\
\text { Bus Iness } \\
\text { Assets } \\
\end{array}$ & $\begin{array}{c}\text { Equity } \\
\text { In } \\
\text { House (s) } \\
\end{array}$ & $\begin{array}{c}\text { Equity } \\
\text { In } \\
\text { Car(s) }\end{array}$ \\
\hline $\begin{array}{l}\text { PINC } \\
\left(1000^{\prime} \mathrm{s}\right)\end{array}$ & $\begin{array}{l}-13 \\
(32)\end{array}$ & $\begin{array}{l}-29 \\
(48)\end{array}$ & $\begin{array}{c}50 \\
(57)\end{array}$ & $\begin{array}{c}-8 \\
(38)\end{array}$ & $\begin{array}{c}481 \\
(110)\end{array}$ & $\begin{array}{c}-1,021 * \star \\
(160)\end{array}$ & $\begin{array}{l}486 * \star \\
(135)\end{array}$ & $\begin{array}{l}54 * \star \\
(20)\end{array}$ \\
\hline $\begin{array}{l}\text { INCDIF } \\
\left(1000^{\prime} \mathrm{s}\right)\end{array}$ & $\begin{array}{c}12 \\
(14)\end{array}$ & $\begin{array}{l}-51 \star \\
(21)\end{array}$ & $\begin{array}{c}-7 \\
(25)\end{array}$ & $\begin{array}{l}45^{\star \star} \\
(16)\end{array}$ & $\begin{array}{l}235 \star \star \\
(42)\end{array}$ & $\begin{array}{c}-331 \star \star \\
(60)\end{array}$ & $\begin{array}{c}38 \\
(51)\end{array}$ & $\begin{array}{l}58 \star \star \\
(8)\end{array}$ \\
\hline $\begin{array}{l}\text { WEALTH } \\
\left(1000^{\prime} \mathrm{s}\right)\end{array}$ & $\begin{array}{l}79 \star \star \\
(9)\end{array}$ & $\begin{array}{l}198 * * \\
(13)\end{array}$ & $\begin{array}{l}631 * * \\
(16)\end{array}$ & $\begin{array}{l}92 \star \star \\
(11)\end{array}$ & $\begin{array}{l}98 \star \star \\
(6)\end{array}$ & $\begin{array}{l}679 \star \star \\
(84)\end{array}$ & $\begin{array}{l}210 * \star \\
(71)\end{array}$ & $\begin{array}{l}13 * \star \\
(1)\end{array}$ \\
\hline AGEHEAD & $\begin{array}{c}16 \\
(23)\end{array}$ & $\begin{array}{l}-55 \\
(36)\end{array}$ & $\begin{array}{c}43 \\
(42)\end{array}$ & $\begin{array}{l}-4 \\
(29)\end{array}$ & $\begin{array}{l}103 \\
(88)\end{array}$ & $\begin{array}{c}-1,169 * * \\
(128)\end{array}$ & $\begin{array}{l}1,028 * * \\
(109)\end{array}$ & $\begin{array}{l}38 * \\
(16)\end{array}$ \\
\hline KIDS & $\begin{array}{r}-109 \\
(60)\end{array}$ & $\begin{array}{l}-68 \\
(92)\end{array}$ & $\begin{array}{l}368 * \star \\
(108)\end{array}$ & $\begin{array}{c}-191 * * \\
(73)\end{array}$ & $\begin{array}{l}-298 \\
(315)\end{array}$ & $\begin{array}{l}-300 \\
(457)\end{array}$ & $\begin{array}{r}817^{\star} \\
(388)\end{array}$ & $\begin{array}{c}-219 \star \star \\
(58)\end{array}$ \\
\hline $\begin{array}{l}\text { WKSWRKW } \\
\left(10^{\prime} \mathrm{s}\right)\end{array}$ & $\begin{array}{c}-3 \\
(41)\end{array}$ & $\begin{array}{l}-44 \\
(63)\end{array}$ & $\begin{array}{c}90 \\
(74)\end{array}$ & $\begin{array}{l}-43 \\
(50)\end{array}$ & $\begin{array}{l}-352^{\star} \\
(146)\end{array}$ & $\begin{array}{c}196 \\
(211)\end{array}$ & $\begin{array}{c}156 \\
(179)\end{array}$ & $\begin{array}{c}0 \\
(27)\end{array}$ \\
\hline CENTCITY & $\begin{array}{l}-206 \\
(214)\end{array}$ & $\begin{array}{c}13 \\
(325)\end{array}$ & $\begin{array}{c}2 \\
(386)\end{array}$ & $\begin{array}{c}191 \\
(260)\end{array}$ & $\begin{array}{r}1,080 \\
(860)\end{array}$ & $\begin{array}{c}1,085 \\
(1,246)\end{array}$ & $\begin{array}{l}-2,007 \\
(1,058)\end{array}$ & $\begin{array}{l}-158 \\
(158)\end{array}$ \\
\hline OTHSMSA & $\begin{array}{c}288 \\
(305)\end{array}$ & $\begin{array}{l}-687 \\
(464)\end{array}$ & $\begin{array}{c}2 \\
(551)\end{array}$ & $\begin{array}{c}397 \\
(371)\end{array}$ & $\begin{array}{c}817 \\
(765)\end{array}$ & $\begin{array}{c}948 \\
(1,109)\end{array}$ & $\begin{array}{c}83 \\
(942)\end{array}$ & $\begin{array}{l}-214 \\
(140)\end{array}$ \\
\hline SOUTH & $\begin{array}{l}-512 \star \\
(212)\end{array}$ & $\begin{array}{c}360 \\
(323)\end{array}$ & $\begin{array}{c}98 \\
(383)\end{array}$ & $\begin{array}{c}54 \\
(258)\end{array}$ & $\begin{array}{c}213 \\
(675)\end{array}$ & $\begin{array}{c}2,987^{\star \star} \\
(978)\end{array}$ & $\begin{array}{c}-3,241 * \star \\
(831)\end{array}$ & $\begin{array}{c}41 \\
(124)\end{array}$ \\
\hline CONSTANT & $\begin{array}{l}-214 \\
(911)\end{array}$ & $\begin{array}{c}1,484 \\
(1,388)\end{array}$ & $\begin{array}{l}-2,758 \\
(1,648)\end{array}$ & $\begin{array}{c}1,488 \\
(1,110)\end{array}$ & $\begin{array}{c}-10,157 * * \\
(3,352)\end{array}$ & $\begin{array}{l}41,251^{\star \star} \\
(4,860)\end{array}$ & $\begin{array}{c}-31,652 \star \star \\
(4,127)\end{array}$ & $\begin{array}{c}559 \\
(616)\end{array}$ \\
\hline $\mathrm{R}^{2}$ & 22.0 & 34.3 & 81.8 & 20.3 & 17.8 & 75.8 & 37.7 & 12.8 \\
\hline
\end{tabular}

*Coefficlent is significant at the 5 percent level on a two-talled test. $\star \star C o e f f i c i e n t ~ i s ~ s i g n i f i c a n t$ at the 1 percent level on a two-talled test. 
Table A-III

Regression Results for Assets, Single Heads

(standard errors)

\begin{tabular}{|c|c|c|c|c|c|c|c|c|}
\hline \multirow[b]{2}{*}{$\begin{array}{l}\text { Explanatory } \\
\text { Var1ables }\end{array}$} & \multicolumn{4}{|c|}{ B1acks $(N=402)$} & \multicolumn{4}{|c|}{ Whites $(N=674)$} \\
\hline & $\begin{array}{l}\text { Net } \\
\text { Liquid } \\
\text { Assets } \\
\end{array}$ & $\begin{array}{c}\text { Net } \\
\text { Business } \\
\text { Assets } \\
\end{array}$ & $\begin{array}{c}\text { Equity } \\
\text { In } \\
\text { House(s) } \\
\end{array}$ & $\begin{array}{c}\text { Equity } \\
\text { 1n } \\
\operatorname{Car}(s) \\
\end{array}$ & $\begin{array}{l}\text { Net } \\
\text { Liquid } \\
\text { Assets } \\
\end{array}$ & $\begin{array}{c}\text { Net } \\
\text { Business } \\
\text { Assets } \\
\end{array}$ & $\begin{array}{l}\text { Equity } \\
\text { In } \\
\text { House (s) } \\
\end{array}$ & $\begin{array}{c}\text { Equity } \\
\text { In } \\
\operatorname{Car}(s) \\
\end{array}$ \\
\hline $\begin{array}{l}\text { PINC } \\
\left(1000^{\prime} s\right)\end{array}$ & $\begin{array}{l}-353^{*} \\
(142)\end{array}$ & $\begin{array}{l}243 \star \\
(99)\end{array}$ & $\begin{array}{c}-21 \\
(125)\end{array}$ & $\begin{array}{l}1311^{\star \star} \\
(42)\end{array}$ & $\begin{array}{c}548 \\
(420)\end{array}$ & $\begin{array}{l}-772 \\
(428)\end{array}$ & $\begin{array}{c}136 \\
(167)\end{array}$ & $\begin{array}{c}87 \\
(150)\end{array}$ \\
\hline $\begin{array}{l}\text { INCDIF } \\
\left(1000^{\prime} s\right)\end{array}$ & $\begin{array}{c}14 \\
(34)\end{array}$ & $\begin{array}{c}-6 \\
(24)\end{array}$ & $\begin{array}{l}-48 \\
(30)\end{array}$ & $\begin{array}{l}40 * * \\
(10)\end{array}$ & $\begin{array}{l}751 * \star \\
(123)\end{array}$ & $\begin{array}{l}-843 * \star \\
(126)\end{array}$ & $\begin{array}{l}-14 \\
(49)\end{array}$ & $\begin{array}{l}106 * \\
(44)\end{array}$ \\
\hline $\begin{array}{l}\text { WEAL_TH } \\
\left(1000^{\prime} \mathrm{s}\right)\end{array}$ & $\begin{array}{l}610 * \star \\
(23)\end{array}$ & $\begin{array}{l}226 \star \star \\
(16)\end{array}$ & $\begin{array}{l}205 * \star \\
(20)\end{array}$ & $\begin{array}{l}59 * * \\
(7)\end{array}$ & $\begin{array}{l}429 \star \star \\
(18)\end{array}$ & $\begin{array}{l}465 \star \star \\
(18)\end{array}$ & $\begin{array}{l}76 * * \\
(7)\end{array}$ & $\begin{array}{l}30 * * \\
(6)\end{array}$ \\
\hline AGEHEAD & $\begin{array}{l}-48 \\
(53)\end{array}$ & $\begin{array}{c}29 \\
(36)\end{array}$ & $\begin{array}{c}19 \\
(46)\end{array}$ & $\begin{array}{c}0 \\
(15)\end{array}$ & $\begin{array}{l}-137 \\
(255)\end{array}$ & $\begin{array}{l}-251 \\
(260)\end{array}$ & $\begin{array}{c}390 * * \\
(101)\end{array}$ & $\begin{array}{c}-2 \\
(91)\end{array}$ \\
\hline RIDS & $\begin{array}{c}-54 \\
(129)\end{array}$ & $\begin{array}{c}1 \\
(89)\end{array}$ & $\begin{array}{c}67 \\
(113)\end{array}$ & $\begin{array}{l}-14 \\
(38)\end{array}$ & $\begin{array}{l}-346 \\
(985)\end{array}$ & $\begin{array}{c}-709 \\
(1,004)\end{array}$ & $\begin{array}{c}1,326 \star \star \\
(392)\end{array}$ & $\begin{array}{l}-270 \\
(353)\end{array}$ \\
\hline FEMHEAD & $\begin{array}{l}-662 \\
(456)\end{array}$ & $\begin{array}{c}292 \\
(316)\end{array}$ & $\begin{array}{c}765 \\
(401)\end{array}$ & $\begin{array}{l}-395 \star \star \\
(134)\end{array}$ & $\begin{array}{c}5,664 * \pi \\
(1,973)\end{array}$ & $\begin{array}{l}-5,561 * \star \\
(2,010)\end{array}$ & $\begin{array}{c}426 \\
(785)\end{array}$ & $\begin{array}{l}-530 \\
(708)\end{array}$ \\
\hline CENTCITY & $\begin{array}{l}112 \\
(483)\end{array}$ & $\begin{array}{c}247 \\
(334)\end{array}$ & $\begin{array}{l}-207 \\
(424)\end{array}$ & $\begin{array}{l}-151 \\
(142)\end{array}$ & $\begin{array}{c}2,366 \\
(2,090)\end{array}$ & $\begin{array}{c}-407 \\
(2,130)\end{array}$ & $\begin{array}{r}-1,190 \\
(831)\end{array}$ & $\begin{array}{l}-769 \\
(750)\end{array}$ \\
\hline OTHSMSA & $\begin{array}{c}348 \\
(640)\end{array}$ & $\begin{array}{l}-348 \\
(443)\end{array}$ & $\begin{array}{l}-638 \\
(562)\end{array}$ & $\begin{array}{c}64 \\
(188)\end{array}$ & $\begin{array}{c}2,507 \\
(1,991)\end{array}$ & $\begin{array}{l}-1,585 \\
(2,029)\end{array}$ & $\begin{array}{c}81 \\
(792)\end{array}$ & $\begin{array}{r}-1,003 \\
(714)\end{array}$ \\
\hline SOUTH & $\begin{array}{c}-1,194 \star \star \\
(442)\end{array}$ & $\begin{array}{l}834 * \pi \\
(306)\end{array}$ & $\begin{array}{c}327 \\
(388)\end{array}$ & $\begin{array}{c}33 \\
(130)\end{array}$ & $\begin{array}{c}1,818 \\
(1,593)\end{array}$ & $\begin{array}{c}-705 \\
(1,623)\end{array}$ & $\begin{array}{l}-694 \\
(634)\end{array}$ & $\begin{array}{l}-419 \\
(571)\end{array}$ \\
\hline CONSTANT & $\begin{array}{r}4,091 \star \\
(1,957)\end{array}$ & $\begin{array}{l}-3,234 * \\
(1,355)\end{array}$ & $\begin{array}{c}-710 \\
(1,720)\end{array}$ & $\begin{array}{l}-147 \\
(576)\end{array}$ & $\begin{array}{l}-9,266 \\
(8,366)\end{array}$ & $\begin{array}{l}18,561^{\star} \\
(8,524)\end{array}$ & $\begin{array}{c}-10,935 \star \star \\
(3,327)\end{array}$ & $\begin{array}{c}1,641 \\
(3,000)\end{array}$ \\
\hline$R^{2}$ & 66.3 & 17.6 & 22.0 & 32.9 & 55.1 & 50.7 & 22.0 & 7.0 \\
\hline
\end{tabular}

*Coefficient is significant at the 5 percent level on a two-tailed test.

**Coefficient is significant at the 1 percent level on a two-talled test. 